\title{
Front Matter: Volume 10927
}

, "Front Matter: Volume 10927," Proc. SPIE 10927, Photonic and Phononic Properties of Engineered Nanostructures IX, 1092701 (24 May 2019); doi: $10.1117 / 12.2531386$

SPIE. Event: SPIE OPTO, 2019, San Francisco, California, United States 


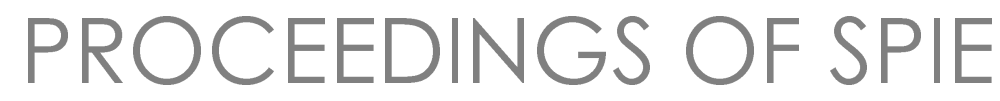

\title{
Photonic and Phononic Properties of Engineered Nanostructures IX
}

\author{
Ali Adibi \\ Shawn-Yu Lin \\ Axel Scherer \\ Editors
}

4-7 February 2019

San Francisco, California, United States

Sponsored and Published by

SPIE 
The papers in this volume were part of the technical conference cited on the cover and title page. Papers were selected and subject to review by the editors and conference program committee. Some conference presentations may not be available for publication. Additional papers and presentation recordings may be available online in the SPIE Digital Library at SPIEDigitallibrary.org.

The papers reflect the work and thoughts of the authors and are published herein as submitted. The publisher is not responsible for the validity of the information or for any outcomes resulting from reliance thereon.

Please use the following format to cite material from these proceedings:

Author(s), "Title of Paper," in Photonic and Phononic Properties of Engineered Nanostructures IX, edited by Ali Adibi, Shawn-Yu Lin, Axel Scherer, Proceedings of SPIE Vol. 10927 (SPIE, Bellingham, WA, 2019) Seven-digit Article CID Number.

ISSN: 0277-786X

ISSN: 1996-756X (electronic)

ISBN: 9781510624962

ISBN: 9781510624979 (electronic)

Published by

SPIE

P.O. Box 10, Bellingham, Washington 98227-0010 USA

Telephone +1360 676 3290 (Pacific Time) · Fax +1 3606471445

SPIE.org

Copyright @ 2019, Society of Photo-Optical Instrumentation Engineers.

Copying of material in this book for internal or personal use, or for the internal or personal use of specific clients, beyond the fair use provisions granted by the U.S. Copyright Law is authorized by SPIE subject to payment of copying fees. The Transactional Reporting Service base fee for this volume is $\$ 18.00$ per article (or portion thereof), which should be paid directly to the Copyright Clearance Center (CCC), 222 Rosewood Drive, Danvers, MA 01923. Payment may also be made electronically through CCC Online at copyright.com. Other copying for republication, resale, advertising or promotion, or any form of systematic or multiple reproduction of any material in this book is prohibited except with permission in writing from the publisher. The CCC fee code is 0277$786 \times / 19 / \$ 18.00$.

Printed in the United States of America by Curran Associates, Inc., under license from SPIE.

Publication of record for individual papers is online in the SPIE Digital Library.

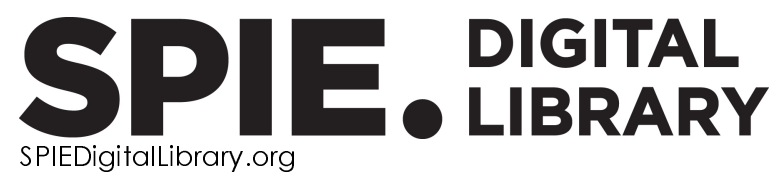

Paper Numbering: Proceedings of SPIE follow an e-First publication model. A unique citation identifier (CID) number is assigned to each article at the time of publication. Utilization of CIDs allows articles to be fully citable as soon as they are published online, and connects the same identifier to all online and print versions of the publication. SPIE uses a seven-digit CID article numbering system structured as follows:

- The first five digits correspond to the SPIE volume number.

- The last two digits indicate publication order within the volume using a Base 36 numbering system employing both numerals and letters. These two-number sets start with $00,01,02,03,04$, 05, 06, 07, 08, 09, 0A, OB ... 0Z, followed by 10-1Z, 20-2Z, etc. The CID Number appears on each page of the manuscript. 


\title{
Contents
}

\author{
$\checkmark \quad$ Authors \\ vii Conference Committee
}

MODELING AND SIMULATION OF NANOPHOTONIC STRUCTURES

10927 OE Transformation optics using finite-difference time-domain method [10927-12]

PHOTONIC METASURFACES I

10927 OF Enhancing harmonics generation by time-variant metasurfaces (Invited Paper) [10927-13]

10927 Ol Transmission and reflection features of all-dielectrics metasurfaces with electric and magnetic resonances [10927-16]

PHOTONIC METASURFACES II

10927 ON Development of nanostructured GRIN microlenses with temperature-controlled diffusion [10927-21]

PHOTONIC MICRORESONATORS

10927 OT Non-reciprocal lasing action in topological cavities of arbitrary geometries [10927-27]

10927 OX Enhanced atom-resonator coupling using superradiance in whispering gallery mode [10927-30]

PHOTONIC CRYSTALS AND OPTICAL METAMATERIALS

10927 OY Optical computing using photonic crystal slabs (Invited Paper) [10927-31]

$1092711 \quad$ Multilayer hyperbolic metamaterial based on alternating $\mathrm{TiO}_{2} /$ Cu layers [10927-34] 
1092712 Engineered nanostructures characterization by spectral interferometric microscopy [10927-35]

$1092713 \quad$ Fabrication and optical characterization of hyperbolic nanoparticles on a transparent substrate [10927-36]

\section{NONLINEAR PHOTONIC NANOSTRUCTURES}

10927 1A Temperature impact on upconversion efficiency and luminescence of erbium-doped ceriaplasmonic nanostructure [10927-43]

10927 1B Plasmonic-based enhancement of light emission due to nonlinear effect at ITO/LiNbO interface [10927-44]

\section{PLASMONIC NANOSTRUCTURES}

10927 IN Molecular spacers in nanocube patch antennas: a platform for embedded molecular electronics [10927-56]

\section{NANOPHOTONIC STRUCTURES FOR SENSING}

10927 IT Hyper sensitive plasmonic optical system for pollutant detection [10927-63]

\section{POSTER SESSION}

$1092721 \quad$ High-contrast imaging of magnetic domains by magneto-optical Kerr effect using plasmon filters [10927-70]

1092729 Active plasmonic nanoantenna-based switch for controlling near-field properties [10927-80]

10927 2A W1 photonic crystal slab waveguide as an ultra-compact TE-pass polarization filter [10927-81]

10927 2B Highly sensitive high-Q discontinuous slotted photonic crystal nanobeam cavity for gas sensing [10927-82]

10927 2C Aligned electrospun polycaprolactone nanofiber matrix as a functional air filter [10927-83] 


\title{
Authors
}

Numbers in the index correspond to the last two digits of the seven-digit citation identifier (CID) article numbering system used in Proceedings of SPIE. The first five digits reflect the volume number. Base 36 numbering is employed for the last two digits and indicates the order of articles within the volume. Numbers start with 00, 01, 02, 03, 04, 05, 06, 07, 08, 09, OA, OB...0Z, followed by 10-12, 20-2Z, etc.

\author{
Abuabed, Alaeddin, 2C \\ Ackermann, Jörg, $1 \mathrm{~N}$ \\ Alisafaee, Hossein, 11 \\ Babicheva, Viktoriia E., ol \\ Bahari, B., OT \\ Baryshnikova, Kseniia $\vee$., Ol \\ Berginc, Gérard, $1 \mathrm{~N}$ \\ Boubiche, Nacer, $1 T$ \\ Brunel, Damien, $1 \mathrm{~N}$ \\ Buczynski, Ryszard, ON \\ Bürgi, Thomas, 12 \\ Chang, Wei-Zung, OF \\ Chen, Zihao, OX \\ Cimek, Jaroslaw, ON \\ Darvill, Daniel, 13 \\ Dhawan, Anuj, 29 \\ Dhawan, Prerak, OE \\ Dilts, James, 11 \\ Duché, David, $1 \mathrm{~N}$ \\ Dumur, Frédéric, $1 \mathrm{~N}$ \\ El Amili, A., OT \\ Elrafei, S. A., 1A \\ Escoubas, Ludovic, $1 \mathrm{~N}$ \\ Evlyukhin, Andrey B., Ol \\ Fainman, Y., OT \\ Fan, Shanhui, OY \\ Filipkowski, Adam, ON \\ Gigmes, Didier, 1N \\ Grillo, Rossella, 12 \\ Guo, Cheng, OY \\ Gupta, Nitin, 29 \\ Hasegawa, T., 21 \\ larossi, Marzia, 13 \\ Isoniemi, Tommi, 13 \\ Jangid, Vikas, $1 \mathrm{~N}$ \\ Javahiraly, Nicolas, IT \\ Kandas, I., 1A \\ Kante, B., OT \\ Karabchevsky, Alina, Ol \\ Kasztelanic, Rafał, ON \\ Lebouin, Chrystelle, $1 \mathrm{~N}$ \\ Le Normand, François, $1 T$ \\ Maccaferri, Nicolò, 13 \\ Margeat, Olivier, $1 \mathrm{~N}$ \\ Minkov, Momchil, OY \\ Mizoshiri, M., 21 \\ Moses, Jeffrey, OF \\ Ndao, A., OT \\ Nguyen, Hue Thi, ON
}

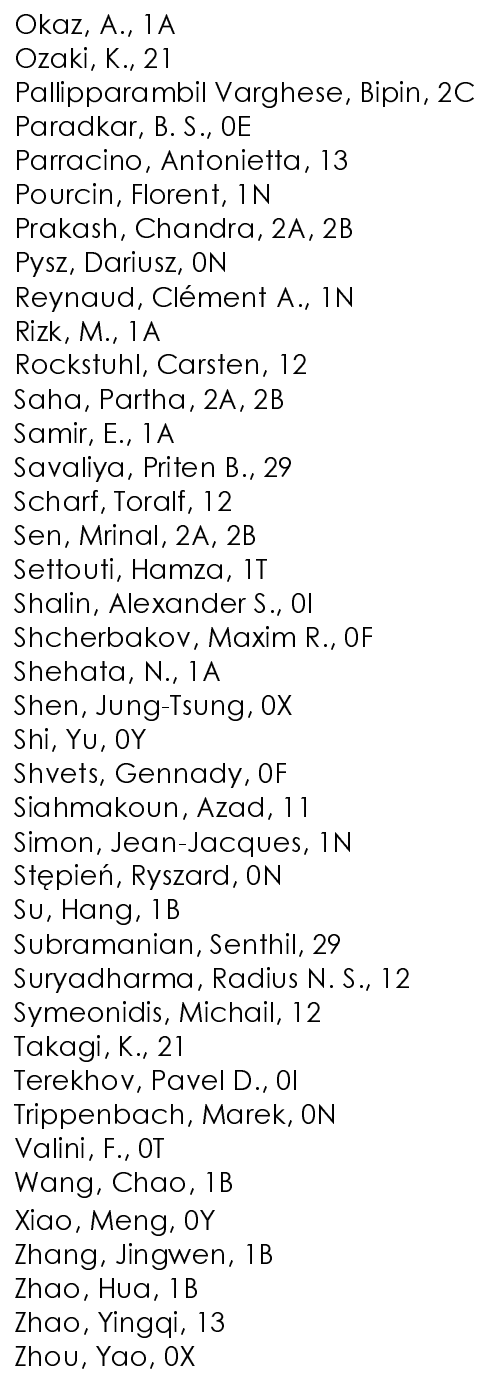


Proc. of SPIE Vol. 10927 1092701-6

Downloaded From: https://www.spiedigitallibrary.org/conference-proceedings-of-spie on 26 Apr 2023 Terms of Use: https://www.spiedigitallibrary.org/terms-of-use 


\section{Conference Committee}

Symposium Chairs

Connie J. Chang-Hasnain, University of California, Berkeley (United States)

Graham T. Reed, Optoelectronics Research Centre, University of Southampton (United Kingdom)

Symposium Co-chairs

Sailing He, KTH Royal Institute of Technology (Sweden) and Zhejiang University (China)

Yasuhiro Koike, Keio University (Japan)

Program Track Chair

Ali Adibi, Georgia Institute of Technology (United States)

Conference Chairs

Ali Adibi, Georgia Institute of Technology (United States)

Shawn-Yu Lin, Rensselaer Polytechnic Institute (United States)

Axel Scherer, Caltech (United States)

Conference Program Committee

Andrea Alù, The City University of New York (United States)

Ali A. Eftekhar, Georgia Institute of Technology (United States)

Mercedeh Khajavikhan, CREOL, The College of Optics and

Photonics, University of Central Florida (United States)

Reginald K. Lee, Caltech (United States)

Marko Loncar, Harvard John A. Paulson School of Engineering and Applied Sciences (United States)

Arka Majumdar, University of Washington (United States)

Susumu Noda, Kyoto University Graduate School of Engineering (Japan)

Masaya Notomi, NTT Basic Research Laboratories (Japan)

Ekmel Özbay, Bilkent University (Turkey)

Yong Xu, Virginia Polytechnic Institute and State University (United States)

Eli Yablonovitch, University of California, Berkeley (United States)

Rashid Zia, Brown University (United States) 
Session Chairs

1 Recent Advances in Engineered Nanostructures

Ali Adibi, Georgia Institute of Technology (United States)

2 Optoelectronics in 2D Materials

Wenshan Cai, Georgia Institute of Technology (United States)

3 Modeling and Simulation of Nanophotonic Structures

Farhan Rana, Cornell University (United States)

4 Photonic Metasurfaces I

Andrea Alù, The City University of New York (United States)

5 Photonic Metasurfaces II

Gennady B. Shvets, Cornell University (United States)

6 Diamond Nanophotonic and Optomechanic Structures

Qing Li, Carnegie Mellon University (United States)

7 Photonic Microresonators

Christoph Becher, Universität des Saarlandes (Germany)

8 Photonic Crystals and Optical Metamaterials

Oliver Benson, Humboldt-Universtät zu Berlin (Germany)

9 Quantum Nanostructures

Cheng Guo, Stanford University (United States)

10 Nonlinear Photonic Nanostructures

Ali Adibi, Georgia Institute of Technology (United States)

11 Phase Change Materials for Optoelectronics

Marko Loncar, Harvard John A. Paulson School of Engineering and Applied Sciences (United States)

12 Novel Materials and Phenomena in Engineered Nanostructures

Mostafa Abdelsalam, The American University in Cairo (Egypt)

13 Plasmonic Nanostructures

Kenneth B. Crozier, The University of Melbourne (Australia)

14 Phononic Crystals and Optomechanical Structures

Toshihiko Baba, Yokohama National University (Japan)

15 Nanophotonic Structures for Sensing

Abdelkrim Khelif, FEMTO-ST (France) 